することは，キルンの前のオイルバルブを開放する 前に必ず庄縮空気のバルブを開いて後徐々に油を少 量づつ放出し，霧化の最良状態を捉之一て調節する(休 止の場合は必ずまずォイルバルブを閉めた後空気を 止める)。

口，加熱用蒸汽はキルンの発熱ボイラの蒸汽を用い る。蒸汽圧力 $14 \mathrm{~kg} / \mathrm{cm}^{2}$ で途中減圧して約 $7 \sim 9 \mathrm{~kg} /$ $\mathrm{cm}^{2}$ 程莈とし，溫度は約 $200^{\circ} \mathrm{C}$ である。キルン 5 基 簐転して約 $500 \mathrm{~kg} / \mathrm{h}$ を使用与る。

八, 压縮空気は $5.5 \mathrm{~kg} / \mathrm{cm}^{2}$ で約 300 馬力を要し, 重 油の理論燃燒空気量に対して約 $3 \%$ 過剩空気を必 要とする。

二, 添入原料の水硬萃は重油專燒の場合ほどクリンカ との差はなく混燒に就いてわずか低下する。

ホ，耐火煉瓦に及济寸影響はキルン內コーチングの附 着状態いかんによるが重油專燒の場合は若干耐火䔶 の点に注意を要す。しかし混燒にてはコーチング附 着もよく石炭專燒の場合と大差ない。

へ，余熱発電も重油專燒の場合は当初低下を考慮した が実績の示すデータによると不炭專等のときと大盖 ないようである。すなわち今後重油の霧化や燃燒方 法に研究を重ねねばならない余地があることを示し ていると思われる。

\section{VII 運転上の注意}

イ、タンク內にある重油量を常に明膫に知るためフロ ート(要すれば自働的聯動装置)などにより測定し， また溢出するのを防ぐ。

ロタンク上部に空気孔を設け，先端は折曲げ金網を かがせて拉く。

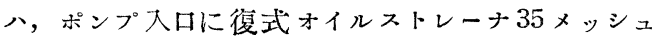
$\left(16 \times 16169\right.$ 孔 $\left./ \mathrm{cm}^{2}\right)$ 設置し交互に点検掃除できる ごとくする。

ニ，蒸汽による加熱の場合には過熱による油の変質を 防止するため正確なる溫度計を取付け，要すれば自 動的に溫度調節をして一定溫度の保持に注意与る。 ホ, 減压弁を設け蒸汽パイプ中の水槌現象を防止する。 へ,オイルバーナや圧縮空気の一部に警報裝置を取㣙 ける。

ト, 最も大切な点はバーナよりオイルのみ噴射して霧 化空気（蒸汽）が止つていることやまた焰が消えて もな抽油噴出しているようなことのないように注 意することである。

チ, 爇器および重油パイプのフランヂパッキングに 特に留意点検すること。

リタンク內のドレンを常に拢出し，なおスラッヂを 溜めないよらに注㲅する。スラッヂの分散剤として ナイコ(商品名) がある(試験中)。また,防火設備 を强化し危険物取扱條令を嚴守せねねばならない。

U.D.C. $666 \cdot 1 / .2+662.94$

\title{
硝子工業 と重油燃燒（抄）
}

一一昭和 28 年 3 月 14 日特別讙演会講演——

旭ガラス株式会社 宮、崎雄一 郎

\section{Iガラスエ業における重油の使用状況} ガラス工場の然燒機に要求される事項は

(a) 主質のガラスを熔解し得ること

(b) 趣設賽が管いこと

(c) 然熆の効率, 労力, 保守が経済的であること で重油のときはこの 3 條件が満足される。

ガラス工業で使用されているバーナの種類は次ざの ようである。

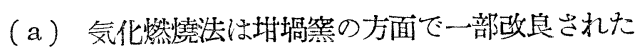
型式で佼用されている。（b）低圧バーナは徐冷珪に 使用されている。（c）高圧空気吹达式が槽窒に用い られている。（d）ジェット・アトマイジングのバー

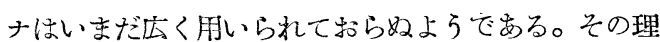

由は熖の拡散度や長さが空気吹込式の方がよいためで ある。

畦堝式の丸塞に重油を用いるには従来の坐ガス発生 此の段炭屝にバーナを取付けて成功している例があ る。これは上述の (a)に当るもので高圧の空気吹达式 を用いてな扮気化然堯法る使つている例である。

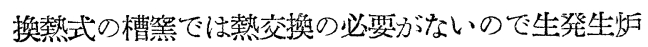
ガスの吹出口に取付けて簡単に重油然燒の特徵を発揮 し好成績を收めていたことは古くからよく知られてい る。

蓄熱式のサイド・ファイァリングの槽黨については 最近まで例も少なく，かつ種々の困䧼があつたが筆者 らの研究や英国の報告をまとめて以下記述する。 
バーナの取付け方式には種々ある。

第 1 図

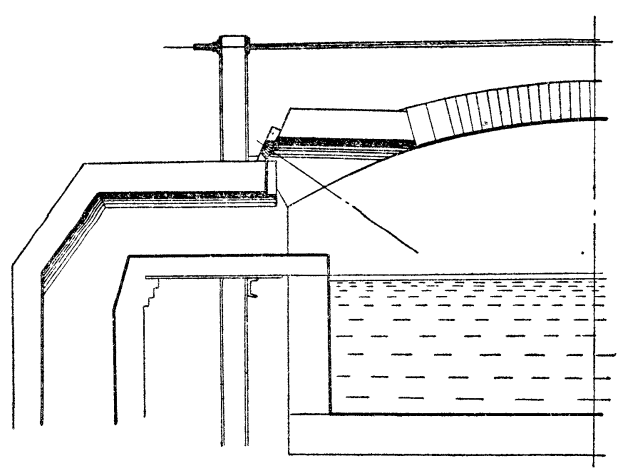

第1図は吹出の天井に取付けたるのである。この式 は大天井と吹出天井の揀瓦積の設計に特別の注意を要 する。バーナの調節も取付け場所の関係から困蜼があ

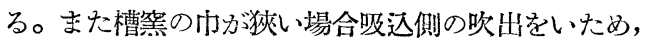
また吹出側に焔のない死角をつくる欠点がある。吸込 になるとバーナを引き出す裝置をつけたものがあり， 好んで用いられている。この式に類似したもので吹出 の後側から水冷されたバーナを吹出口の中に突き込儿 だものがある。

第 2 図

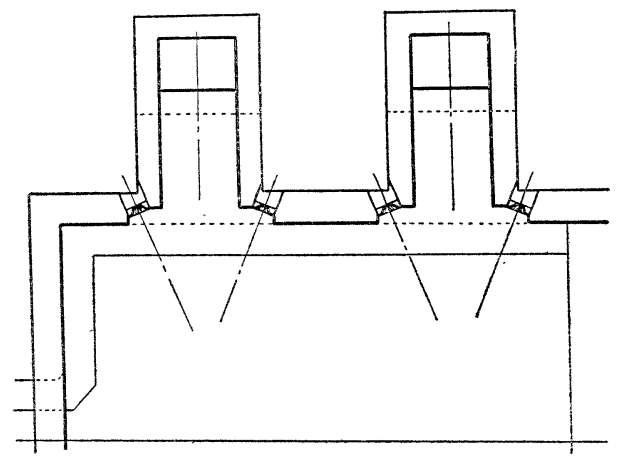

第2図は吹出口の両側から入れたものである。この 型式は一般に好まれない。吹出の間にあるバック・ス テーが邪䇫になつて吹出の間隔を広く取らねば取付け 䧼いこと, 両側の焰が不均衡になり吹出の桂の重要部 分を過熱する危険があること，バーナ・フレームが交 叉して本来の熠の形を乱すことなどの久点がある。

第 3 図は後壁から吹出す方式である。この式は築筧 上簡単で促来の慒嘿になんら变更を加えないで行える ので広く採用されている。旉㷵の形が大きくなるとト ウィン・バーナを設けて第1のバーナはずつと先で燃 光るように强い鈆角で欣き出し，第 2 のバーナは手前 で早く燃えるように設計してある。

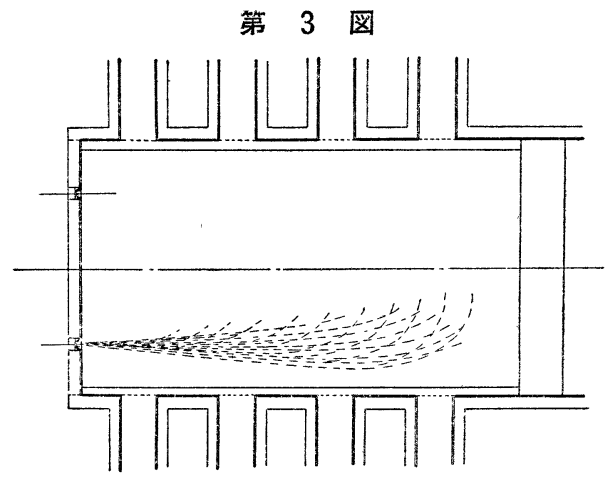

第 4 図は最新式の設計で吹出の所にバーナ・ブロッ クをもつてきている。バーナの保守のために䉒瓦に沿 つて吹出の下に通路を必要とする。皕の方式は発生炬 ガス然燒の場合に最も理想的の状態になる。しかしバ 一ナの保守とバーナ・ブロックの煉瓦の質とその設訐 上から從来の発生炕ガスの筀のままこれを利用するこ とは困難がある。

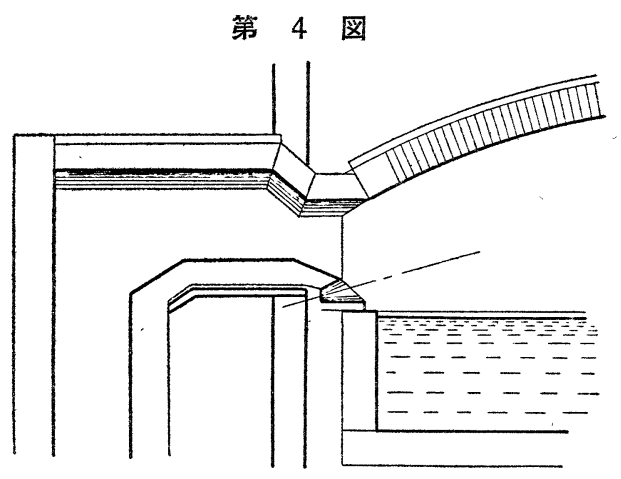

\section{II 重油燃燒上の特徽}

槽筧の設計が满点で，使用炕材が適正であり良好な バーナを設計撰択しその取付けがよければ，重油燃燒 は他のいずれの燃料と比較しても満足すべきであるこ とは自然の理である。

(a) そこで問題となるのはバーナの掃除とその保 守である。これには取除しが自由で交代ごとに検查す ることを要する。さらに予犕のバーナは常に保持する 必要が岕る。

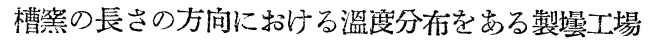
の筀にとつた一例是示すが(第 5 図), 発生炬がス焚の 場合には炬の寿命が長くなるとともに蓄熱室がつま り, 吹出口のいた2も重なつて適正な溫港分有が困難 となる。重油燃蹺の場合は格子積の溫度が泜く，つま りが少なく，さらに重油の量の加減が自由にできるた めに溫茛分布の配置は楽に保持できる。 
第 5 図

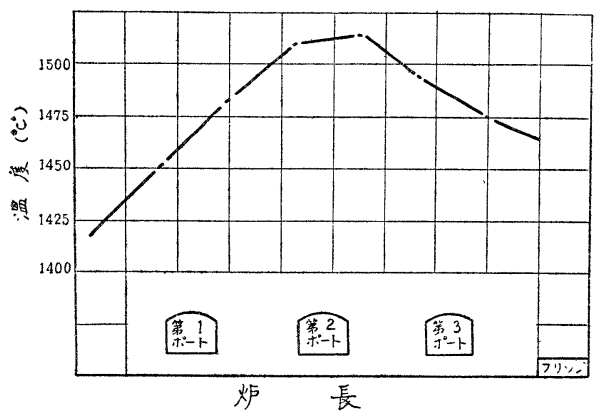

（b）焰からの伝熱は焔の長さに関係することが夫 である。燃燒速度と焔の長さを支配するものは燃料と 二次空気の混合である。発生炬ガス焚の場合には竿の 㺃重が多くなり䉥の寿命が長くなるとともに烚が長く なる原因はガスを余計に出してガラスを余訐に熔かそ 万とするからである。吹出口が傷及ガス空気の混合が 惡くなりガスの宿は段々と長くなる。そのために反対 側の吹出を傷め，さらに格子積を傷め，スラッグのつ ホりができて煙突の熱損失は多くなる。

重油燃煏の場合は霧化がよければ燃料, 空気の混合

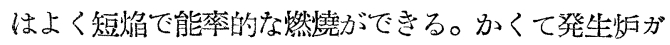
スの場合と反対に荷重を增してもまた詹の寿命が長く なつても，常に一定に良質のガラスを作ることができ る。

第 6 図

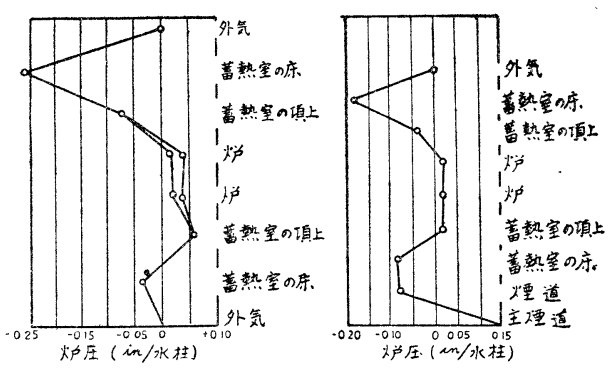

（c）槽篣のシステムの圧力は第 6 四のごとく保持 されこれを一定にうまく保持することは良質のガラ スを作り䉥の操作を效率よくしその寿命を長めるため に重大なことである。前述のよらに格子積のつまりの 少ないこととその溫度の低いことは，このシステムの 圧力の保持によいことはもち論で重泊燃燒の重大な特 徵である。

第 7 図

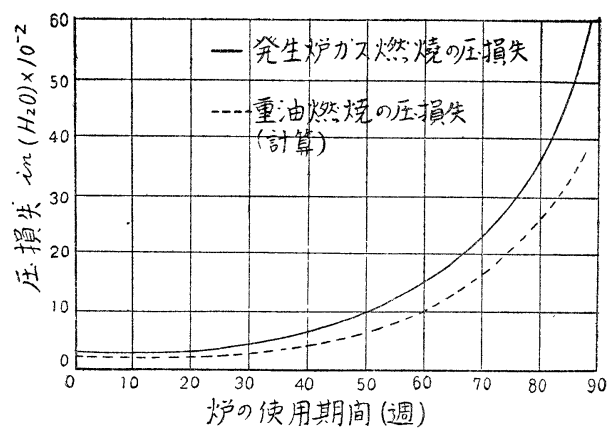

第7 図に発生炊ガスと重油焚の場合を比較した空気 蓄熱の圧損失の変化を示した一例を示す。

（d）石炭では一定の規格の品位を常に保持するこ とはなかなか困難な事情がある。重油の場合は涀格を 示しておけば熱量, 品位, 粘度などの要求は常に一定 に保持することはさほど困難ではない。

（e）筀の荷重と溫度の調笁も発生炬の場合よりも 楽に取り得らるる特長がある。

（＜wide>）耐火材料が重油燃燒の場合鹪久易いのは局部 加熱を受け易いからである。これについてはバーナ・ ブロックや局部加熱を受け易い場所での耐火材の撰 択，バーナの型式の撰定，筧の設訫などが関係する点 が大きい。米英などの諸国でも種々の設計がいろいろ そ試みられたがいずれも一長一短で失敗の歷史が多い ように思われる。ゆえに設計に当つては特に填重な考 慮が必要である。

以上は 3 月14日案業協会との共催にて行われた「重油とバーナ」に関する特別講演会における 講演であるが，紙面の関係上そのうち 5 編は資技試 田中楠爾太氏に括願いして抄錄していただ いたものである。その全交については「䇺業協会誌」7月号を御覽願いたい。 